\title{
Factors Affecting GRDP and Efficiency Level of Food Crops Sub-sector in East Java
}

\author{
Dhany Hermansyah $^{1 *}$, Nuhfil Hanani ${ }^{2}$, Abdul Wahib Muhaimin ${ }^{2}$ \\ ${ }^{1}$ Graduate Program, Faculty of Agriculture, Brawijaya University, Jl. Veteran, Malang 65145, Indonesia \\ ${ }^{2}$ Socio-economic Department, Faculty of Agriculture, Brawijaya University, Jl. Veteran, Malang 65145, \\ Indonesia
}

Received: 19 May 2017; Revised: 4 July 2017; Accepted: 11 July 2017

\begin{abstract}
The strategic roles of agriculture are provider of food and raw material for the industry, as well as contributor of Gross Regional Domestic Product (GRDP), foreign exchange earnings, and the main employer. Based on the total GRDP of agriculture, food crops have the highest value compared to other subsectors. However, when compared to other sectors, the the total GRDP of the agricultural sector inin East Java is still lower than that of the manufacturing and trade sectors. To increase its contribution, agricultural sector needs policies, regulations, programs and specific intervention for food crops performance in each district. The objectives of the study were to analyze factors affecting the GRDP of food crops sub-sector in East Java, and to analyze the efficiency level of the food crop sub-sector in the districts/cities in East Java. The research method was the Stochastic Frontier Analysis with Front 4.1 application. The dependent variable was GRDP of food crops, and the independent variables consist of irrigated land, dry land area, the number of agricultural labors, the number of subsidized fertilizer, the subsidized of two-wheel tractors, and water pump. Based on the survey, the factors that significantly influence the GDP were irrigated land area, dry land area, number of employees, and subsidized twowheeled tractors. The findings suggested that the area of irrigated land, dry land, the number of labor, and the subsidized two-wheel tractor had significant effect towards the GRDP of the food crops sub-sector. However, the amount of subsidized fertilizer and water pump assistance did not significantly affect the GRDP of the food crops sub-sector. The average efficiency level of the food crops sub-sector in East Java was 0.77 with a minimum efficiency of 0.44 in Mojokerto City and the maximum efficiency in Gresik was 0.96. The central regions of the food crop sub-sector had an average of high efficiency, while the low-efficiency regions were the urban areas.
\end{abstract}

Keywords: GRDP; food crop subsector; efficiency

\section{How to cite:}

Hermansyah, D., Hanani, N., \& Muhaimin, A. W. (2017). Factors Affecting GRDP and Efficiency Level of Food Crops Sub-sector in East Java. HABITAT, 28(1), 22-27. https://doi.org/10.21776/ub.habitat.2017.028.1.4

\section{Introduction}

The agricultural sector is one of the strategic sectors in supporting economic growth and development. In the third phase of the national middle-term development plan/ RPJMN (2015-2019), the agricultural sector is still an important sector in the national economic development. The strategic roles of the agricultural sector are illustrated in the contribution of the the sector as providers of food

${ }^{*}$ Corresponding Author.

E-mail: dhanyhermansyah@gmail.com

Telp: +62-858-1139-1329 and raw materials for the industry, contributors to Gross Regional Domestic Product (GDRP), foreign exchange earners, absorbing labors, the main source of rural household income, food and bioenergy providers, and important element to reduce greenhouse gas emissions (Ministry of Agriculture, 2015).

In terms of the contribution for East Java GRDP, the agricultural sector still ranks third after the industrial and trading sector. The declining role of the agricultural sector is due to, among others, decreasing productivity, less supportive policies, and low use of agricultural technology by farmers (the National Development Planning Agency, 2005). Out of the 
total GRDP of the agricultural sector, the food crops sub-sector has the highest value and contribution compared to the other sub-sectors. Wirakusuma, et.al (2015) stated that regional autonomy could hardly improve food crop subsector in East Java and as the consequence, it ranked below the livestock sub-sector.

The performance of agricultural sector can be identified based on GRDP of the sub-sectors in agriculture and the input variables; the study will discuss food crops sub-sector. GRDP may be an indicator of sectoral economic activities through production, expenditure and revenue approaches presented based on current prices and constant prices. Furthermore, one can analyze factors affecting GRDP.

Another issue to identify is efficiency level of each city/municipality in East Java in terms of using development input resources to support the GRDP of the food crops sub-sector. Out of the 38 cities/municipalities in East Java, each has different characteritics and agricultural resources. GRDP of each city/municipality shows the total production that is influenced by some input variables. Regions with high GRDP are not always ones with high level of efficiency in using their resources. As the result, the government of East Java should establish more specific policies, programs and interventions related to the performance of the food crop sub-sector in each city/municipality in East Java.

The objectives of the study were to analyze (1) factors affecting GRDP of the food crop subsector in East Java and (2) level of efficiency of the food crop sub-sector in each city/municipality in East Java.

\section{Research Methodology}

The study lasted between January and April, 2017 using secondary data related to the 2015 food crop sub-sector. Some consideration of selecting East Java as the setting of the study were agriculture was one of the primary sector in East Java development, the province has high GRDP in food crop sub-sector, and it is one of the national food barns due to high production of food crops.

The study used the stochastic frontier analysis. The method was able to analyze between regression simultaneously showing which factors affecting output and efficiency level of each city/municipality in East Java, which became the objects of observation.
Cobb-Douglass production function was adapted to specify frontier production function for each city/municipality in East Java. The frontier production function was as follow:

$Y_{i t}=\prod_{n=1}^{8} \alpha X_{n i}^{\beta_{n}} e^{\left(v_{i}-u_{i}\right)}$.

Description:

$\mathrm{Y} \quad=$ Food crop sub-sector GRDP (billions of rupiahs)

$\mathrm{X}_{1 \mathrm{i}} \quad=$ Irigated land $(\mathrm{Ha})$

$\mathrm{X}_{2 \mathrm{i}} \quad=$ Dry land $(\mathrm{Ha})$

$\mathrm{X}_{3 \mathrm{i}} \quad=$ Number of labors (person)

$\mathrm{X}_{4 \mathrm{i}} \quad=$ Subsidized fertilizer (ton)

$\mathrm{X}_{5 \mathrm{i}} \quad=$ Subsidized two-wheel tractor (unit)

$\mathrm{X}_{6 \mathrm{i}} \quad=$ Subsidized water pump (unit)

$v \quad=$ Random error $\left(\mathrm{N}\left(0, \sigma_{v}{ }^{2}\right)\right)$

$u \quad=$ Inefficiency effect

$\alpha$ and $\beta=$ Estimated parameter

$i=$ city/municipality

$\mathrm{u}_{\mathrm{i}}$ was non negative random variable that functioned as measurement for technical inefficiency in production with assumption that it was independently distributed in $N\left(\mu_{i}, \sigma_{u}^{2}\right)$ (Coelli, 1996).

Rather important characteristics of the Stochastic production frontier for technical efficiency estimation was separating impact of exogenous variable shock towards output with contribution of variance in the form of inefficiency (Giannakas, et al. 2003).

The following step was to test the parameters using $\mathrm{t}$-test to prove whether the independent variables individually affected the dependent variable. The following formula was used to determine the t-statistics.

$t=\frac{\widehat{\beta_{1}}}{s e\left(\widehat{\beta_{1}}\right)}$.

When $\mathrm{t}$ was higher tan the t-table, independent variable had significant influence towards dependent variable and vice-versa.

The following formula described varience of the observation score towards frontier score.

$\sigma^{2}=\sigma_{v}^{2}+\sigma_{u}^{2}$.

When sigma square $=0$, production was operating at the frontier point, but when the sigma square $>0$, there is discrepancy between the frontier and the actual scores. Sigma square score in frontier analysis is the total of inefficiency and random error effect (Coelli, et. al, 2005). On the other hand, gamma $(\gamma)$ showed percentage of composite error caused by technical inefficiency. Mathematically, the gamma score was represented as follow:

$\gamma=\frac{\sigma_{u}^{2}}{\left(\sigma_{u}^{2}+\sigma_{v}^{2}\right)}$. 
Series of test may be conducted in order to test accuracy of stochastic $(v-u)$ or deterministic $(v)$ model, for instance LR test. According to Coelli, et.al (2005), formula of the LR test was as follow:

$L R=-2\left[\ln \left\{L\left(H_{0}\right)\right\}-\ln \left\{L\left(H_{1}\right)\right\}\right]$

When LR $>X^{2}(J)$, the null hypothesis (deterministic) was rejected or in other words, the alternative hypothesis (stochastic) was accepted, and vice-versa.

\section{Results and Discussions}

The stochastic frontier analysis using Front 4.1 application consisted of two stages. On the first stage, Ordinary Least Square (OLS) was the method used analyzed the function to describe the average performance of output achievement process. The Maximum Likelihood Estimation (MLE) was the method used on the second stage. It described the best practice of respondent or object being observed; the objects in the study referred to municipality/city in East Java.

These methods identified the best performance of each city/municipality in using input or existing factors to achieve its GRDP and also estimated the overall parameters of production, intercept, as well as variance of both error components. The independent variables consisted of irrigated land (X1), dry land (X2), number of labors (X3), the amount of fertilizer (X4), number of tractor (X5), and number of water pumps (X6).

A. Factors Influencing GRDP of Food Crop Sub-Sector

Estimation using the Maximum Likelihood Estimation (MLE) method showed that all variables had positive coefficient, , which mant the correlation between each of the variables towards output was positive as well. Among the variables, there were four variables with significant influence $(\alpha=1 \%)$, namely the irigated land, dry land, number of labors and the twowheel tractors. On the other hand, those that did not have significant influence were the amount of fertilizer and the number of water pumps.

The sigma square and gamma scores of the model were 0.1284 and 0.9375 that were significant when the level of error was $1 \%$. The sigma square was variance of the observation score towards the frontier score indicating whether or not there was gap between the actual and the frontier scores and whether or not technical inefficiency was an influential factor. When sigma square $\sigma=0$, there was no gap between the actual and frontier scores or it had been operating at the frontier point. When sigma square $\sigma>0$, the sigma square in the study was 0.1284 , there was gap between the actual and frontier score.

The gamma score was 0.9375 or close to 1 showing that error in the model taking place due to $93.75 \%$ of the technical inefficiency effect $\left(u_{i}\right)$. At the opposite, when gamma score was closer to 0 , the cause of the whole error term was noise or any disturbance from outside the model $\left(\mathrm{v}_{\mathrm{i}}\right)$.

LR test score was 2.0511 with 0.1 of significance and 1 of restriction. The LR score was higher than the critical score which based on the table was 1.642 (Kodde and Palm, 1986). Based on these cores, the stochastic model $(v-$ $u$ ) was accepted because LR test $>X^{2}(J)$.

The following table described the regression of the sthocastic frontier function in GRDP of food crop sub-sector and the influential factors.

Table 1. Estimated Parameter of Stochastic Frontier Function of the Food Crop Sub-sector GRDP in East Java based on the Maximum Likelihood Estimation (MLE) Approach

\begin{tabular}{lccc}
\hline \multicolumn{1}{c}{ Variable } & Coefficient & Standard Error & t-statistic \\
\hline Intercept & -2.3052 & 0.3792 & $-5.3668^{*}$ \\
Irigated land (X1) & 0.3058 & 0.0661 & $4.6268^{*}$ \\
Dry land (X2) & 0.1205 & 0.0328 & $3.6645^{*}$ \\
Number of Labors (X3) & 0.3117 & 0.0745 & $4.1785^{*}$ \\
Subsidized fertilizer (X4) & 0.0277 & 0.0269 & 1.0292 \\
Subsidized two-wheel tractor (X5) & 0.2869 & 0.0672 & $4.2661^{*}$ \\
Subsidized water pump (X6) & 0.0271 & 0.0474 & 0.5715 \\
Sigma squared & 0.1284 & 0.0448 & $2.8680^{*}$ \\
Gamma & 0.9375 & 0.0891 & $10.5235^{*}$ \\
\hline Log Likelihood Function & 4.5868 & & \\
LR-test of the one-sided error & 2.0511 & & \\
\hline
\end{tabular}


Description: *level of significance 1\% ( $\alpha=1 \%)$, ** level of significance 5\% $(\alpha=5 \%,)^{* * *}$ level of significance $10 \%(\alpha=10 \%)$

The coefficient of the irrigated land was 0.3058 (positive) and the level of significance was $1 \%$. The amount of the irrigated land had positive correlation and significant influence towards rice production. It similar to the finding of the previous study conducted by Kusnadi, et.al (2011) in the areas considered as the national rice barn including East Java.

The dry land also had significant influence even though the coefficient was lower than the irrigated land; the coefficient of the dry land was 0.1205 . The dry land is one of the sub-optimal areas for developing food crop because it is vast and has high level of acceptability. Certain type of technology was needed to improve food crop commodity in the area (Subiksa, et.al, 2012).

The number of labor had the highest coefficient score compared to the other variables. It is in line with Fitria (2014) that labor had positive correlation and significant influence towards GRDP of agricultural sector as well as higher elasticity than other factors such as investment. These show that agriculture is labor intensive sector as it absorbs more employees than other sectors. However, Enu and Obeng (2013)'s study argued that labor had negative correlation towards GRDP in agriculture. It happened since the number of labors had reached the optimum quantity and hiring more people would decrease its contribution towards GDP.

The coefficient of the subsidized fertilizer was 0.0277 and it did not have significant influence towards the GRDP. It is predicted that the farmers had yet used the fertilizer effectively as stated in the Regulation of the Ministry of Agriculuture and Governor of East Java about the allocation and the highest retail price of subsidized fertilizer.

Rachman (2009) stated that there were several elements to be taken into account in order to use the subsidized fertilizer effectively, namely increasing accuracy in determining demand and allocation subsidized fertilizer, increasing monitoring and supervision in production and distribution of the subsidized fertilizers, and increasing distribution of the subsidized fertilizer.

The coefficient of the two-wheel tractor was 0.2869 and it had significant influence towards the GRDP when the level of error was $1 \%$. Two-wheel tractor became more popular more particularly in Jawa since the ricefield was getting smaller (Tambunan and Sembiring, 2007). Some facilities should be established to support the farming equipment, for example repair shop, spareparts and programs of which purpose is to increase farmers' skills in using the equipment.

The coefficient of the water pump was 0.0271 and it did not have significant influence towards the GRDP of the food crops sub-sector. In 2015 , the total number of subsidized water pump in East Java was 1,922 units. The water pumps had yet had significant influence towards the GRDP because it is pretty limited in number and due to uneven distribution especially in areas with vast amount of dry land.

\section{B. Efficiency Level of Food Crops Sub- Sector \\ Based on the analysis using the Front 4.1,} the average efficiency level of the food crops sub-sector in East Java was 0.77; it ranged from 0.44 to 0.96 . Mojokerto had the lowest efficiency level, 0.44, while Gresik Municipality had the highest one, 0.96. The areas of which efficiency level was between 0.44 and 0.55 were Mojokerto, Trenggalek Municipality, Batu City, and Situbondo Municipality. Furthermore, the areas of which efficiency level was between 0.56 and 0.75 were Pacitan Municipality, Pamekasan, Malang, Bondowoso, Ponorogo, Kediri, Blitar, Kota Blitar, Bangkalan, Pasuruan City, and Malang City. The remaining cities/municipalities were categorized as ones of which efficiency level was between 0.76 and 0.96 .

Table 2. Efficiency Level of Food Crops SubSector in the Cities/ Municipalities in East Java

\begin{tabular}{lcc}
\hline $\begin{array}{c}\text { Efficiency } \\
\text { Score } \\
\text { Interval }\end{array}$ & $\begin{array}{c}\text { Number of City/ } \\
\text { Municipality }\end{array}$ & $\begin{array}{c}\text { Percentage } \\
(\%)\end{array}$ \\
\hline $0.44-0.55$ & 4 & 10.5 \\
$0.56-0.75$ & 11 & 29 \\
$0.76-0.96$ & 23 & 60.5 \\
\hline \multicolumn{1}{c}{ Jumlah } & 38 & 100 \\
\hline $\begin{array}{l}\text { Average } \\
\text { efficiency }\end{array}$ & 0.77 & \\
\hline Min. & 0.44 & \\
efficiency & & \\
\hline Max. & 0.96 & \\
efficiency & & \\
\hline
\end{tabular}


Based on the analysis, it may be concluded that there was approximately $23 \%$ potentials that had yet been maximized due to the effect of inefficiency. It shoed that the government still had room for improving their food crops subsector GRDP by maximizing the relevant inputs and establishing specific policies and intervention of which purpose was to improve the GRDP in the area.

\section{Policy Implications}

Saptana (2012) explained that efforts to improve agricultural performance and efficiency were making changes in several aspects, for example changing motivation for farming from traditional farming to agribusiness. The second effort was farming activities should have adequate economic stake. The third was there should be a change in farming system from convential ones with traditional input and lowskilled labor to intensive farming of which bases were modern input and skillful labor. The last was that farming activities should have sufficient capital and improvement of market structure, be it the input and output market.

Most of the cities/ municipalities in East Java had pretty high efficiency level which meant the majority of the input had been maximized even though there was a gap between the actual and the frontier scores.

The government should maintain stability of production and farming activities of the areas that had agricultural resources, high GRDP and efficiency level in order to maintain contribution of agriculture towards the economics in general. Furthermore, the government should conduct intervention for the area with a lot of potential for agriculture but low efficiency in order to increase their output and improve their GRDP. In other words, the government should sort out which programs that fit for certain areas. They should take resources and inputs the areas had as consideration prior to making decision on which policy or intervention suitable for the areas.

\section{Conclusion}

The factors that have significant influence and positive correlation towards the GRDP of the food crops sub-sector in East Java are irrigated land, dry land, number of farmers and subsidized two-wheel tractors. At the opposite, the ones that do not have significant influence towards the GRDP are the subsidized fertilizer and water pump.
The average efficiency of the food crop sub-sector in East Java is 0.77 . Mojokoerto has the lowest inefficiency (0.44) and Gresik Municipality had the highest efficiency (0.96). The areas considered as the local food barn have relatively high efficiency while those with low efficiency are urban areas (cities).

In general, the main factors supporting the performance of the food crops sub-sector in East Java are land, labor, and agricultural facilities and infrastructure. The government should pay close attention to these three factors so that the the food crop sub-sector has bigger contribution to East Java economics.

\section{Daftar Pustaka}

Badan Perencanaan Pembangunan Nasional. 2005. Kajian Model Pertumbuhan Sektor Pertanian Untuk Penyusunan Strategi Pembangunan Pertanian. Direktorat Pangan dan Pertanian Bappenas. Jakarta.

Coelli, T.J. 1996. A Guide to FRONTIER Version 4.1 : A Computer Program for Stochastic Frontier Production and Cost Function Estimation. Working Paper. University of New Englang. Australia.

Coelli, Timothy J, D.S. Prasada Rao, Christoper J.O'Donnell, George E. Battese. 2005. An Introduction to Efficiency and Productivity Analysis. Springer. United States of America.

Enu, P., and Obeng, Prudence A. 2013. Which Macro Factors Influence Agricultural Production in Ghana. SAVAP International Journals, Part II: Social Science and Humanity, 4 (5): 333 - 346.

Fitria, Ikawati. 2014. Pengaruh Investasi Swasta dan Tenaga Kerja Terhadap PDRB Sektor Pertanian, Subsektor Tanaman Pangan, Perkebunan, Peternakan. Tesis. IPB. Bogor.

Giannakas, K., Tran, K. C., and Tzouvelekas, V. 2003. On The Choice of Functional Forms in Stochastic Frontier Modeling. Empirical Economics, 28: 75-100.

Kementerian Pertanian. 2015. Rencana Strategis Kementerian Petanian Tahun 2015 - 2019. Jakarta. 
Kusnadi, N., N. Tinaprilla, S.H. Susilowati, dan A. Purwoto. 2011. Analisis Efisiensi Usahatani Padi di Beberapa Sentra Produksi Padi di Indonesia. Jurnal Agro Ekonomi, 29 (1) : 25-48.

Rachman, Benny. 2009. Kebijakan Subsidi Pupuk: Tinjauan Terhadap Aspek Teknis, Manajemen dan Regulasi. Analisis Kebijakan Pertanian, 7 (2): 131 - 146.

Saptana. 2012. Konsep Efisiensi Usahatani Pangan dan Implikasinya Bagi Peningkatan Produktivitas. Jurnal Penelitian Agro Ekonomi, 30 (2): 109-128. PSEKP - Kementan. Bogor.

Subiksa, Sukarman, Ai Dariah. 2012. Prospek Pertanian Lahan Kering Dalam Mendukung Ketahanan Pangan. Badan Litbang Kementan, Bogor.

Tambunan, A.H. dan E. Namaken Sembiring. 2007. Kajian Kebijakan Alat dan Mesin Pertanian. Jurnal Keteknikan Pertanian, 21 (4): $1-16$.

Wirakusuma, Gilang., H. Perwitasari, Irham. 2015. Peran Sektor Pertanian di Provinsi Jawa Timur Pada Sebelum dan Setelah Pemberlakuan Otonomi Daerah. MEDIAGRO, Vol. 11, No. 1:1-11. 